\title{
Recreational home owners in the leadership and governance of peripheral recreational communities
}

\author{
Grete KINDEL ${ }^{1}$ and GARri RAAGMAA ${ }^{2}$
}

\begin{abstract}
This paper addresses recreational home owners' role in local leadership and governance, focusing on whether they counteract or reinforce the peripheralisation of remotely located communities. If recreational house owners (RHO) grow in number, they become stronger stakeholders with an increased ability to impact the social and economic life of communities. Possessing high interpretive and network power, they should have fairly good opportunities to contribute to local development. The greatest challenge is to find a balance and create positive synergies between permanent and temporary residents' interests. Here, leadership quality has a great importance in orchestrating relations and communication between interest groups. Empirically, the paper is based on a comparative case study of Noarootsi and Vormsi, two tiny municipalities located on the Estonian West coast, which is outside the daily commuting area of urban centres. Both case study areas have similar cultural and historical development paths and economic bases. Since they practiced very different leadership models during the last 25 years, we can compare whether and how this impacted governance and overall development. We used media analysis, statistical data and the results of students' fieldwork as a background; moreover, we conducted 20 in-depth interviews with key informants. The results show the highly important role of RHOs in local governance depending on their personal background and motives. At the same time, the results also indicate the need for skilful local leadership to encourage the participation and equal involvement of all permanent and temporary resident interest groups in decision making.
\end{abstract}

Keywords: leadership, governance, recreational home owner, recreational periphery, Estonia

\section{Introduction}

This paper analyses the role of the group of recreational home owners (RHO) in the leadership and governance of peripheral communities. Recreational, also labelled second, leisure, vacation, weekend, holiday, beach, country or seasonal homes include luxurious mansion-type buildings, small houses, shanties, cabins, cottages, ski chalets, trailer homes, and static caravans (MARCOUILlER, W.D. and Chraca, A. 2011). Müller uses the term "second home", which is not entirely correct since some families own three or even more such properties (MüLLER, K.D. 2002).
We define recreational peripheries as territories outside the daily commuting areas of urban centres where a significant part of the population lives temporarily, mainly during the summer and weekends, and mostly uses land for recreational purposes such as various sports, minor hobby cultivation, mushroom and berry picking. RHOs often remain invisible in statistics: they are included neither in the population registers nor in tourism accounts. Nevertheless, whereas a RHO is 'likely to be less concerned with the fate of the community where resides and more with activities that may be scattered throughout the [urban] field but are closest to interests, leading to a stronger identification on his part with the realm' (FriedmanN, J. and Miller, J.

\footnotetext{
${ }^{1}$ Faculty of Economics, University of Tartu. Narva mnt 4, Tartu, Estonia. E-mail: grete.kindel@ut.ee

${ }^{2}$ Department of Geography, University of Tartu. Vanemuise 46, Tartu, Estonia. E-mail: garri@ut.ee
} 
1965, p. 317), then an active and motivated member of a local community may well contribute to its development. Otherwise, RHOs may also create problems for permanent residents (FARSTAD, M. 2011) and reinforce peripheralisation processes when blocking development initiatives in the local council because of their desire for peace and quiet.

The RHO phenomenon and their impact has been well described by several authors (Gallent, N. et al. 2003; Gallent, N. 2007; Paris, C. 2009; Farstad, M. 2011; Rye, F. and Berg, G.N. 2011; Marcouiller, W.D. and Chraca, A. 2011; Nordin, U. and Marjavaara, R. 2012; Nordbo, I. 2014) but so far, the literature on the participation of RHOs in local leadership and governance is fairly limited, thus, it deserves a more thorough investigation.

The restructuring of local power can counteract or reinforce peripherality. On the one hand, new people usually see new horizons, initiate new developments, apply new ways of governance, and, especially when speaking about RHOs, extend networking (bridging social capital). On the other hand, a power shift usually causes conflicts and a negative image of a place, leading to further peripheralisation due to the marginalisation of some groups who may not be involved in the governance any more.

Following this reasoning, we chose the following questions to clarify RHOs' role in local leadership:

- How do RHOs' motives and behaviour impact socialisation with local community?

- How do different representation/leadership models impact local relations and the involvement of RHOs in local decision making?

- What are the main lessons for leadership when involving RHOs in local governance? We carried out a comparative case study in two municipalities on the Estonian West coast. The paper consists of the following sections: (i) the theoretical overview of the recreational home phenomenon and leadership connection based on a literature review, (ii) a presentation of the case study areas and the RHOs' activities in different leadership regimes, and (iii) finally, our conclusion.

\section{Literature review}

The choice of location with recreational homes is influenced by natural conditions (Marcouiller, W.D. and Chraca, A. 2011; LipkinA, O. 2013). City people are willing to consume qualitatively different amenities that they cannot access or afford in urban areas and, thus, they are looking for more distant places to charge their batteries. Recreational homes are located mainly in areas of valuable natural environment: coastland, islands or mountains and places of social and cultural meaning (GALLENT, N. et al. 2003; Dijst, M. et al. 2005; PItKÄNen, K. 2008; Norris, M. and Winston, N. 2010).

It is typical for places of tourism to be in the periphery. In this way, remote regions economically benefit from factors which cannot be utilised otherwise: high mountain chains, barren, rocky landscapes, heather, unproductive dunes' (Christaller, W. 1963, p. 96). Friedmann and Miller described the spreading urban field and the increasing attractiveness of the periphery to metropolitan populations. (Friedmann, J. and Miller, J. 1965, p. 315). It has space, it has scenery, and it contains communities that remain from earlier periods of settlement and preserve a measure of historical integrity and interest'. Thus, recreational land use in geographical peripheries has been described over 50 years ago already.

The mobility of people has increased due to rising welfare and ever widening car ownership (Pettersson, R. 1999; Dijst, M. et al. 2005; Moss, L.A.G. 2006). Less densely populated wealthy countries and regions in Northern America and Europe have witnessed increasing recreational commuting (MüLlER, K.D. 2002; Dijst, M. et al. 2005; Pitkënen, K. 2008; Paris, C. 2009; Norris, M. and Winston, N. 2010; Marcouiller, W.D. and Chraca, A. 2011; LipkinA, O. 2013). A growing number of people live and consume in two or more places. The most of geographically remote areas suffered from a steady demographic downward trajectory over decades nevertheless, several touristic and seasonal living areas have been subject to positive, so called post-productivist development (Halfacree, K. 2006), as tourists 
and recreational house dwellers contributed to the increase of population (at least seasonally), as well as to retail and service consumption significantly. Increasing flows might justify investments into local infrastructure from the national budget and also by private developers.

On the other hand, permanent residents and RHOs may compete for local resources (FARSTAD, M. 2011); extensive recreational house ownership may increase the tax burden of local residents and even cause the displacement of the 'native' population (HALL, C.M. 2010). Local people's attitude towards RHOs depends foremost on their interest and readiness to contribute to the communities' social and cultural life (FARSTAD, M. 2011). Recreational house owners' socialization with the local community depends on their personal willingness to communicate, the existing institutional set up, the settlement structure, and also on the attitude and activities of local governments. RHOs may enrich local close-knit communities with bridging and linking social capital and create additional opportunities (e.g., drag in public or also private investments from outside, increase the knowledge level of local entrepreneurs) and improve the quality of life in a locality (Robertsson, L. and MarjavaAra, R. 2014).

On the basis of literature, we can outline the following factors explaining recreational house purchases:

(1) According to compensation theory people obtain and visit second homes because their permanent home doesn't offer fully acceptable living conditions (Norris, M. and Winston, N. 2010).

(2) Life-cycle theory distinguishes the first stage when people with children are looking for a quiet and child-friendly environment (GALLENT, N. et al. 2003) and the second stage before or after retirement when people are willing to move out of the city to find a calm and beautiful environment for living (Norris, M. and Winston, N. 2010). Both groups are looking for lower-priced and less centrally located housing.

(3) Investment theories explain the purchase of a second house as an investment by those whose credit ratings are good and those who have possibilities to invest their savings (Norris, M. and Winston, N. 2010).

(4) The availability of free land is also an important factor (RYE, F. and BERG, G.N. 2011), explaining why recreational housing is much more represented on the sparsely populated edges of Europe (Nordic countries, Eastern Europe and the Mediterranean) and peripheral regions further away from cities.

(5) Increasing mobility and ever widening car ownership allows people to commute between second and permanent homes (RYE, F. and BERG, G.N. 2011).

(6) Last but not least, rural idyll also attracts RHOs (Müller, K.D. 2002; PitKÄNEN, K. 2008; RYE, F. and BERG, G.N. 2011).

The above reasons normally combine. Usually, RHOs are well educated and wealthier people (Dijst, M. et al. 2005), own a car for commuting (Stewart, S.I. 2002; Moss, L.A.G. 2006) and are seeking a place where they can spend their leisure time and raise children (LunDHOLM, E. 2006). PERLIK found that RHOs usually prefer places with social networks and people who share their views, life-style and culture (PERLIK, M. 2010). If RHOs grow in number, they become stronger stakeholders with an increased ability to impact the social and economic life of communities (KaLtenborn, B.P. et al. 2009). RHOs are normally better educated (Dijst, M. et al. 2005; Nordbo, I. 2014) and have higher interpretive power than the locals. They may lack network and resource power (SoTARAUTA, M. 2009) locally, but have better networks on the national and international level. Combining the strengths and resources of permanent and temporary residents has great potential for positive synergies.

At the other extreme, in the case of conflicts and opportunistic behaviour, a great deal of energy might be wasted on internal fights. Local politicians may even focus on RHOs or their business related interests and leave permanent residents and their problems on the back seat (GALlent, N. 2007). The greatest challenge for the communities of recreational areas is to find a balance and synergy between permanent and recreational residents. 
Nordin and MarjavaARA found that RHOs' involvement in local communities is an important factor in avoiding possible conflicts (Nordin, U. and MarjavaARA, R. 2012). GALlENT uses the term "dwelling hierarchy" which means that different parties are communicating with each other and it is the foundation for a strong and uniform community (Gallent, N. 2007). Rye and Berg point out that the second home phenomenon influences the social structures of communities horizontally and enhances their social and cultural heterogeneity through embracing new people and traditions in the area (RYE, F. and BERG, G.N. 2011). Time and common experiences create a basis for social communion causing positive development (FAlK and Kilpatrick 2000; op. cit. Gallent, N. 2007). Social capital creating process can help to build a community, where common bases are evoked by trust and a growing well-being (GALLENT, N. 2007), as well as a collaborative governance approach (Purdy, J.M. 2012).

FARSTAD found that RHO involvement in local community depends on how much they are interested in local life and how much they are ready to contribute to it (FARSTAD, M. 2011). RHOs often consider from their own interests, demanding privileges, rights, authority and local resources without giving anything in return. They do not consider local needs and they are interested in topics that are connected to their property or environment directly or implicitly. Usually, they protest against any developments which can damage their living environment. On the positive side, RHOs may contribute to the improvement of employment, consuming local products and services (e.g., pushing snow, selling firewood and vegetables, doing repair works) that stimulates the local economy (MüLleR, K.D. 2002; Rye, F. and BERG, G.N. 2011). In addition, RHOs ought to pay taxes to the local municipality. Consequently, if the RHOs manage to improve local economic and social qualities, they are accepted more by the community. Thus, leadership quality has a great importance in orchestrating relations and communication between different interest groups.
However, their contribution could be even stronger. Giannias, D. et al. (2010) point out that local power in peripheries is often locked in and avoids innovations. According to BARCA, F. (2009), 'rent-seeking' local elites restrain critical social innovations and hinder potential economic development (investments, new business entries). Can we consider RHOs, when they are sufficiently embedded in the local communities, as people who can break path dependency or, as DAFT, L.R. (1998) writes, as people 'participating in change' and predisposed to innovation (Sotarauta, M. 2009)? Can RHOs become local leaders or at least join and encourage leadership processes? Under what conditions and in what way might that happen? What consequences may this intervention have?

Horlings, I. (2010), Sotarauta, M. (2012) and RaAgmaA, G. et al. (2012) examined the role of public sector leaders and found that they have an essential role in igniting new local/regional development and social capital creating process. However, Mintzberg, $\mathrm{H}$. (1998) stressed that the followers and teams around leaders are no less important. How can RHOs as potential agents of change motivate local people? Do they understand each other and do they share similar values? Quite often, RHOs have an active social life in their recreational destination (due to family ties, friendship) and rather limited communication with their neighbours in their city apartments or suburban neighbourhoods. RHOs possessing high interpretative and network power (SotARAUtA, M. 2009) have fairly good opportunities to contribute to local leadership and to enter local governance structures.

\section{Methodology and data}

RHOs remain 'invisible' in population statistics or are incorrectly registered because of the rigidity of the registration systems that do not account for people's increased mobility (Marcouiller, W.D. and Chraca, A. 2011). RHOs are normally embedded into local community affairs one way or another. 
It is common that after many years of statistical invisibility, a recreational homeowner being part of the community and local decision making for years registers and becomes a permanent resident. Therefore, we chose the case study method, focussing on interviews attempting to pinpoint and describe causal processes and identify the real involvement of part-time residents in local governance.

The methodological frame of this study is based on SAYER's critical realism (SAYER, A. 1992). He states that the traditional (positivistic) social science approach usually describes the top of the iceberg without seeking deeper casual relations. Therefore, we compared the social phenomena of two municipalities, using KedDIE's comparative case study methodology (Keddie, V. 2006). Campell, S. et al. (2010) explained how this method helps to study the context and the characteristics of concrete phenomena: the comparative case study aims to find contrasts, similarities and patterns of different cases, thus, it rests on the combination of different sources and data.

We chose two rural municipalities - Noarootsi and Vormsi in West Estonia with a high share of recreational population (Figure 1). Both of them are well-discussed

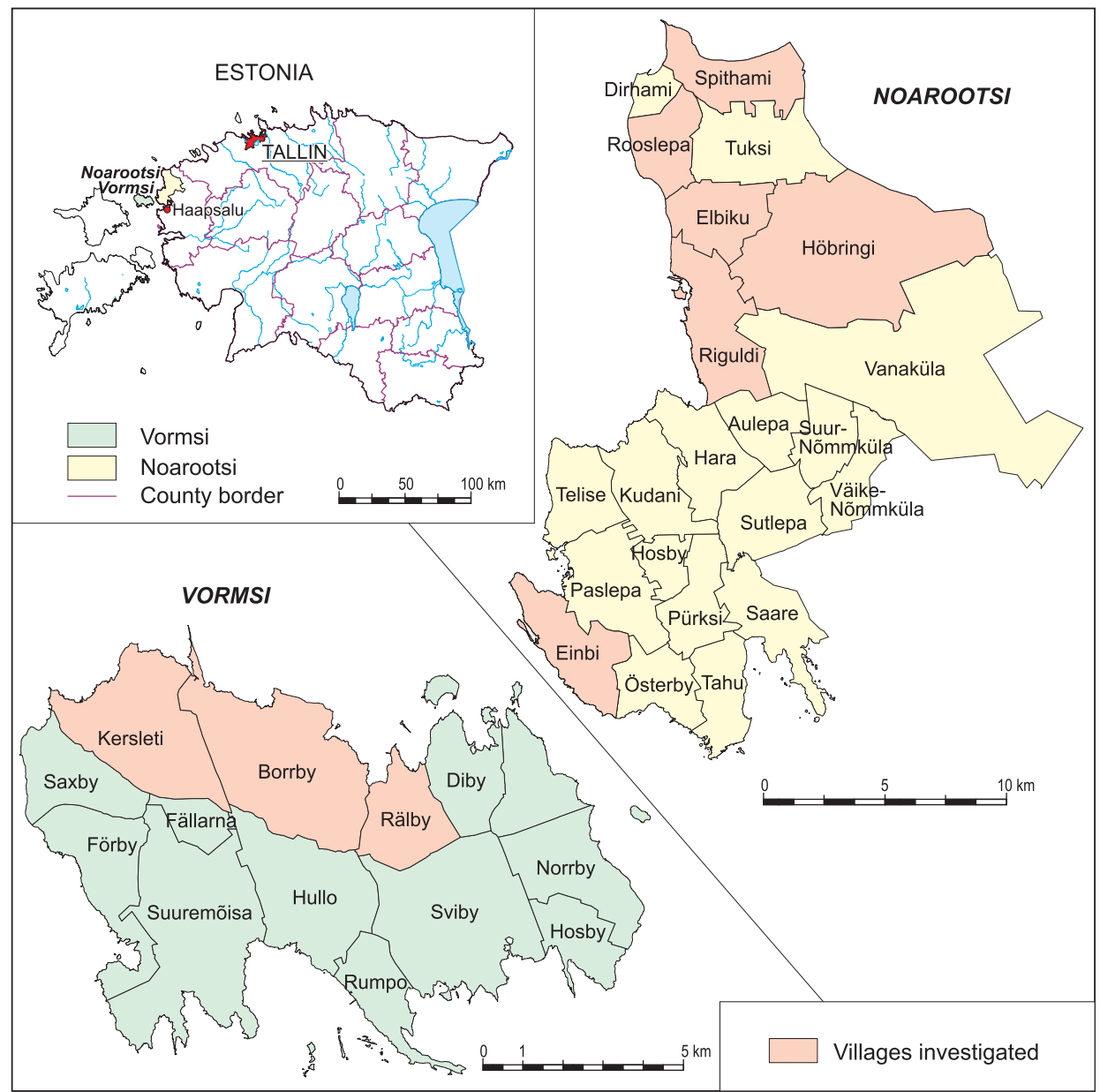

Fig 1. Location of Noarootsi and Vormsi municipalities inside Lääne county in West Estonia. In case of their 9 villages extra investigations were carried out 
in the national media because of local power struggles. These two municipalities are recreational peripheries: located outside the daily commuting area of the regional capital Haapsalu. They have attracted numerous second house owners form the capital city Tallinn and abroad (mainly Sweden). Basic data for booth municipalities can be seen in Table 1.
The content analysis materials were collected from the Lääne County newspaper Lääne Elu and two national newspapers Maaleht (rural weekly) and Eesti Päevaleht (daily). The main keywords were 'Vormsi', 'Noarootsi', 'Estonian Swedes' and 'elections'.

After choosing the fields and analysing their conditions, the study plan was updated and then, twenty in-depth semi-structured

Table 1. Basic data for the investigated rural municipalities

\begin{tabular}{l|c|c|c|c|c|c|c|c}
\hline \multirow{2}{*}{ Municipality } & \multirow{2}{*}{$\begin{array}{c}\text { Area in } \\
\mathrm{km}^{2}\end{array}$} & \multicolumn{3}{|c|}{ Population, person } & \multicolumn{4}{c}{ Driving distance from } \\
\cline { 3 - 9 } & & 1934 & 1989 & 2015 & $\mathrm{~km}$ & minutes & $\mathrm{km}$ & minutes \\
\cline { 3 - 9 } & 296 & 4,388 & 909 & 840 & 110 & 90 & 37 & 30 \\
Noarootsi & 93 & 2,547 & 347 & 412 & 123 & $240^{*}$ & 25 & $150^{*}$ \\
\hline
\end{tabular}

*Including ferry

Noarootsi and Vormsi have a similar cultural background (the areas were populated mainly by Swedes before World War II) and RHOs actively participate in local governance. At the same time, they have had different leadership practices in the past: Noarootsi was ruled by one strong charismatic leader for 22 years (1987-2009), whereas Vormsi has had a constantly changing weak local leadership.

For the background study, we made a media analysis and analysed statistical data provided by the Statistics Estonia and the National Electoral Committee. Moreover, we employed students to collect recreational housing fieldwork data in the selected Noarootsi and Vormsi villages in 2014 and 2015 (Table 2).

Table 2. Recreational households in the villages of the two municipalities

\begin{tabular}{|c|c|c|c|c|}
\hline \multirow[t]{2}{*}{ Municipality } & \multirow[t]{2}{*}{ Villages } & \multirow{2}{*}{$\begin{array}{c}\text { Total } \\
\text { number of } \\
\text { households }\end{array}$} & \multicolumn{2}{|c|}{$\begin{array}{l}\text { Recreational } \\
\text { households }\end{array}$} \\
\hline & & & number & $\%$ \\
\hline \multirow{6}{*}{ Noarootsi } & Elbiku & 48 & 32 & 66.7 \\
\hline & Einbi & 47 & 31 & 66.0 \\
\hline & Höbringi & 14 & 9 & 64.3 \\
\hline & Riguldi & 47 & 38 & 80.9 \\
\hline & Rooslepa & 26 & 21 & 80.7 \\
\hline & Spithami & 34 & 31 & 91.2 \\
\hline \multirow{3}{*}{ Vormsi } & Kersleti & 15 & 8 & 53.3 \\
\hline & Borrby & 16 & 15 & 93.8 \\
\hline & Rälby & 24 & 18 & 75.0 \\
\hline
\end{tabular}

interviews were conducted with former and actually appointed mayors, civil servants, NGO leaders, village elders, municipality council members and RHOs involved in local affairs between November 14, 2012 and May 23, 2014. Each conversation was recorded and transcribed.

The interview guide covered the following topics:

(1) identity and community feeling,

(2) interpersonal relations and social capital,

(3) leadership, and

(4) governance.

The identity questions aimed to figure out different local sub-groups. The questions addressing social relations and capital revealed permanent residents' and RHOs' relations and their involvement in community life. Leadership and governance-related questions helped to understand the motivations behind power changes.

\section{The formation of recreational population in Noarootsi and Vormsi}

Noarootsi rural municipality covers an area of $296 \mathrm{~km}^{2}$ in Lääne County, western Estonia. According to the population register, 840 inhabitants lived in Noarootsi municipality on 
July 1, 2015. The real situation is different, as a number of registered inhabitants are RHOs and students living elsewhere. The average population density in Noarootsi is very low ( 3 persons per $\mathrm{km}^{2}$ ). Nevertheless, local population is tripled in the summer season. Noarootsi has about $100 \mathrm{~km}$ of sandy coastline, and it is highly attractive as a recreational area. Its main economic activities are tourism, wood processing, forestry and agriculture (Photo 1).

Vormsi, Estonia's fourth largest island (93 $\mathrm{km}^{2}$ ) is located in also in Lääne County, on the Western part of Estonia and has 14 villages. On July 1, 2015, Vormsi had 417 registered inhabitants (4.3 persons per $\mathrm{km}^{2}$ ), Nevertheless, in statistical estimations, three-quarters of them do not live there permanently. An additional motivation for registering on the island comes from the 50 percent discount on ferry tickets for local people. Vormsi population has also been fluctuating recently due to the so-called election migration, such as to the registration of trusted voters on the island. In 2011, many people signed out because of the new land taxation system and of the availability of free public transport in Tallinn. Vormsi Isle is desirable for RHOs from Tallinn because of its closeness to the capital and its insularity. The dominant economic activities in Vormsi are tourism, forestry and agriculture (Photo 2).

Our case study area used to be the area inhabited by Estonian Swedes or Costal Swedes (in Swedish Estlandssvenskar and colloquially, Aibofolke) in the largest number before World War II. The beginning of continuous settlement in these areas (known as Aiboland) dates back to the $13^{\text {th }}$ century. According to the 1934 census, 7,641 Estonian Swedes lived in Estonia. About 7,000 of them fled to Sweden in 1944 (EE 2014) and only a few of them chose to stay. Newcomers from the mainland settled in the area and additional

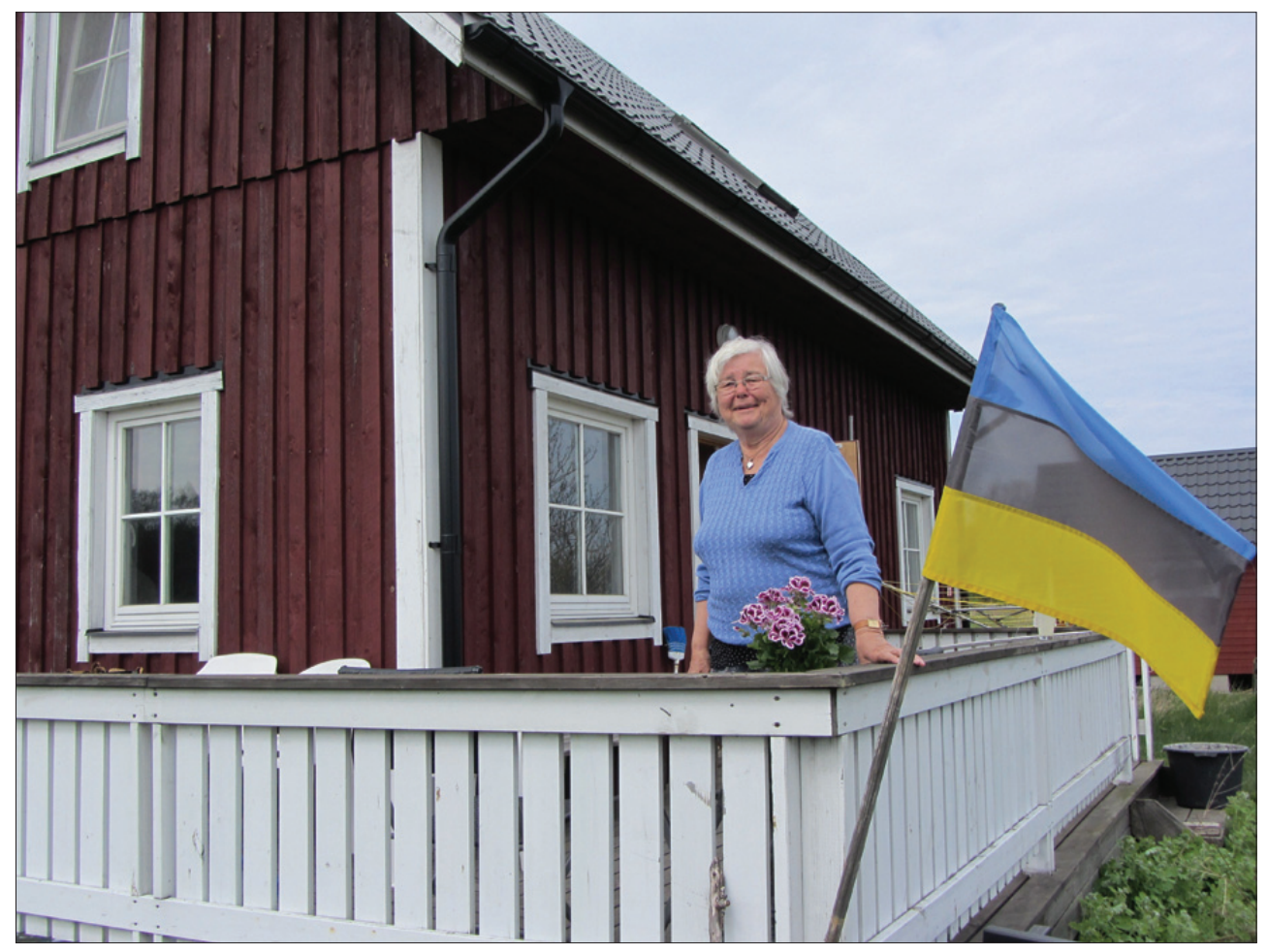

Photo 1. Permanent Estonian-Swedish inhabitant with Aiboland's flag in Noarootsi 


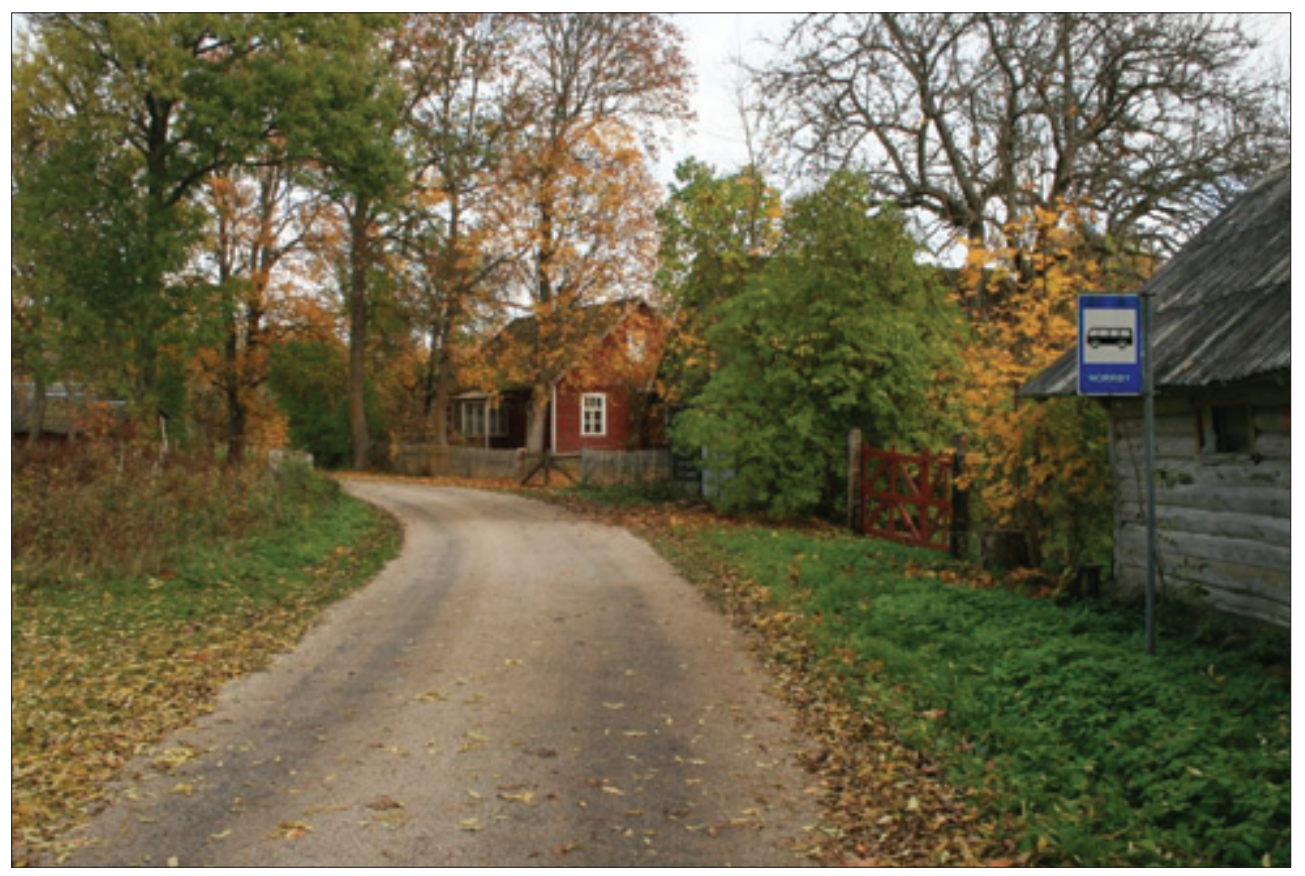

Photo 2. Norby village street view in Vormsi (Photos by G. KINDEL)

permanent residents were attracted to the area by the organisation of collective farms.

During the Soviet time, migration in the border zones was strictly controlled. Regardless of the border regime, next to the permanent residents, an access to the area was also granted to the Communist Party elites who were able to get building permits for new summerhouses or to purchase local farmhouses and renovate them as summer cottages. Owning a second house on the coast and particularly, on the islands has gained popularity among the political elites and intellectuals since the 1970s. By 1980 Vormsi and Noarootsi were already functioning as recreational housing areas. Additionally, several industrial enterprises and central government organisations set up their holiday house complexes and camps there. Therefore, the first generation of RHOs had a specific elitist background. Several former RHOs still live in the area as permanent residents; they are well embedded in the local networks and generally respected by other people.
Estonia initiated a restitution-based land reform in 1992 that returned property to prewar owners and their heirs. The majority of Estonian Swedes used this opportunity but some of them either disclaimed or sold their land to new people, mainly to the new RHOs from Tallinn. The majority of Swedish people did not return as permanent residents, but started to use their property for recreational purposes. The formation of new recreational house communities was different in Noarootsi and Vormsi.

The Swedish returnees and other new land owners were always welcome by the Noarootsi Mayor, Ülo Kalm. His aim was to increase the number of permanent residents (thus, personal income tax revenues) and for this he tried to convince RHOs to register in the Noarootsi municipality. Meanwhile, the Vormsi municipality decided not to return land to Estonian Swedes and proposed to create small zones where Estonian Swedes could build their recreational homes. This idea was not supported by the Estonian Parliament and accelerated the 
conflict between Estonian Swedes and Vormsi municipality. As a result of the disputes, the majority of Estonian Swedes got back their land but not the houses which were inhabited by new bona fide owners.

According to the 2011 census, 77 Estonians owned a second house in Vormsi and 236 in Noarootsi municipality (Statistics Estonia 2014). Today, Noarootsi and Vormsi RHOs are mainly middle-aged, well-educated, well-off people that confirms earlier research results on the structure of RHO population (e.g. Dijst, M. et al. 2005; Lundholm, E. 2006). Second home owners from the 1990s onwards are mainly from Tallinn, and they are wealthier than locals and the 1970s RHOs. Newcomers have more contacts with each other and with their neighbours.

The interviewees complained about that the newcomers have a strong NIMBY mentality; they often fight against new developments or for their own business projects. Relationships between Estonian RHOs and permanent residents depend on specific persons. The interviewees found that the RHOs' open-mindedness and their understanding of local habits help to pursue an easy life together. Warmer relationships are settled with the RHOs who have been there for a long time and who take part in the locals' projects and events. Some RHOs are members of local NGOs and help to arrange local actions. Nevertheless, a number of recreational home owners do not want to take part in any local actions and prefer to stay isolated in peace and quiet.

RHOs from Sweden were not included in Estonian Census data. According to our interviews and the students' fieldwork (Bø, E. et al. 2014; ТАMм, H. et al. 2015), about half of the RHOs in Roslepa and Spithami villages in Noarootsi and 10-30 percent in Borrby, Kersleti and Rälby villages in Vormsi are Estonian Swedish (AusDaHL, K. et al. 2014). They are overwhelmingly elderly people who are attached to their property because of their historical roots - the personal or their parents' memories - and the idyll of the beautiful coastal landscapes. According to municipal landowner registers, about 30 percent of Noarootsi (2012) and 80 percent (2011) of Vormsi land belongs to people living outside of Estonia, mostly Estonian Swedes.

The majority of Estonian Swedes visit the area once a year. They are not interested in agricultural production, thus, they let their land to local farmers. Estonian Swedes pursue social activities in the summer, but these events are solely for the 'insiders'. Estonian Swedes' organisations such as RiguldiNoarootsi Union in Noarootsi and Vormsi Kodukandi Union mainly attempt to maintain old traditions. Permanent residents think, that Estonian Swedes are peaceful and do not participate in local governance.

\section{Governance and leadership in Noarootsi and Vormsi}

The municipality councils in Noarootsi as well as in Vormsi have nine members. Five parties in Vormsi and four parties and one single candidate in Noarootsi ran for the municipal council membership at the last (2013) elections. Noarootsi municipality has had four mayors between 1990 and 2014 and Vormsi municipality had 12 mayors subsequently.

Vormsi and Noarootsi municipalities practiced entirely different leadership styles until 2009. While Noarootsi experienced 22 years of sustained governance under one leader, Vormsi mayors were frequently replaced. Noarootsi mayor Ülo Kalm took office in 1987 as Pürksi Village Soviet chairperson when Estonia was still part of the Soviet Union. He was elected mayor after the establishment of the municipal system in Estonia and continued in that position through several re-elections until 2009. He arguably relied on broadly defined collaborative governance but due to his parentage, the municipal development action was clearly focussed on the development of Estonian-Swedish cultural heritage that used to be dominant in the area before the 1940s. Ülo Kalm, as a descendant of Estonian Swedes achieved very warm contacts with the Estonian-Swedish community that contributed significantly to local development. 
The building of the so-called Coastal Swedish (Rannarootsi in Estonian) identity was definitely successful and the municipality became a popular touristic and recreational housing destination. However, the reestablished Estonian-Swedish community is small and consists mainly of elderly RHOs recently. The Swedish people have not been extensively integrated into the local networks due to the language barriers, thus, they have a rather weak position in the local leadership. This gradually ageing and weakening community could not support the mayor in accomplishing his Estonian-Swedish agenda. Moreover, permanent residents and Estonian RHOs did not fully understand and accept the mayor's plan for uplifting of the vanishing Estonian-Swedish culture and community. Thus, the promotion of Coastal-Swedish identity could not be successful.

Estonian RHOs created a local party 'Better Noarootsi' for the 2009 elections. The personal motivation of RHOs and their representatives was predominantly related to new real estate developments and spatial planning procedures. They won 5 of the 9 local council mandates as they managed to get the support of the other RHOs. During the election campaign, they promised that Ülo Kalm would be reelected but finally, they invited a new mayor. Voters who had thought that Ülo Kalm would be appointed again, thus, supported the RHO party were in shock. Local people collected 311 signatures to support Ülo Kalm, but the new council elected Aivar Kroon, a Noarootsi RHO and businessman as a mayor. Quite soon, he was replaced by a professional administrator Annika Kapp, an outsider from North-Estonia. Noarootsi informants stressed that municipal development was hindered significantly after Ülo Kalm had left; there were considerably fewer events and projects. Estonian Swedes emphasized that they had lost their connection with the municipality just because nobody was able to speak Swedish.

The majority of Vormsi mayors were businessmen who attempted to lead the municipality like a company. Some of them had no real connection with the local people and even tried to manage the municipality from outside Vormsi, visiting the municipal office only while the meetings. Naturally, council members could not tolerate this. The municipality council had elected and then dismissed 12 mayors between 1991 and 2015 subsequently. Somewhat surprisingly, Vormsi people did not consider the endless change of mayors a substantial issue, because the most influential council members were always the same. Interviewees considered the frequently changing leadership as a consequence of the small size of the community and of the conflicts between permanent residents and RHOs stemming from their very different views on local life. Whereas permanent residents are mostly concerned with the availability and quality of local services they need in their daily practices (kindergarten, school, shop, etc.), while RHOs who consume those services at their permanent places of residence are concerned rather with ferry traffic, roads, power and security. To achieve their own goals, the latter group started to play power games. They joined the local party 'Wintertime in Vormsi too' (In Estonian: Ka talvel Vormsil) and registered their friends from the mainland to Vormsi to increase the number of trusted voters.

Actually, they carried out an electoral fraud that was reported even in the national media. 'Wintertime in Vormsi too' won the 2009 election, getting 5 mandates of the available 9 . Two businessmen elected for the Vormsi council initiated a wind farm project immediately. This was unacceptable for both the permanent residents and also for RHOs. 169 people joined the meeting arranged by the municipality (2010) to discuss the windmill project that was finally rejected. It was the very first time when the majority of Vormsi people had a joint political action based on a consensus.

Nevertheless, there have been series of conflicts between permanent inhabitants and RHOs' representatives in the local council of Vormsi since the establishment of local government. RHOs were always active in influencing council members' decisions. Despite its small scale, there are no relationships 
based on trust on the island: networks are either focused only on the villages or are temporary and dominated by interest groups related to projects that need approval within the municipal council. Similarly to Noarootsi, the main motivation of Estonian RHOs for intervening in local governance was to accomplish their business ideas, for instance, to change the local planning regulations or to get a construction permit.

\section{Conclusion}

Townspeople's growing incomes and extending opportunities to spend leisure time in geographically distant areas has increased their desire to possess property in the countryside with beautiful landscapes. Vormsi and Noarootsi rural municipalities - our case study areas - are coastal villages that were turned into recreational destinations and obtained a highly seasonal character. Recreational peripheries may well benefit from increased temporary population, who may act not only as consumers but also as active community members, able to enrich the bridging and enhancing the social capital of the communities. Nevertheless, so far, the involvement of RHOs in local leadership and governance has been studied insufficiently. This paper was an attempt to reduce this gap by analysing the power relations of the RHOs and the permanent population and by discussing whether the restructuring of local power reinforced or reduced peripherality.

According to Frisvoll, S. (2012), social relations are crucial in the local cultural and economic development of rural peripheries. The synergies may work in both directions. Improving interpersonal relations and increasing social capital stimulates innovativeness and competitiveness (HorLINGs, I. 2010) that presupposes vital social relationships between RHOs and the local community. Otherwise, segregation, competitive behaviour, and the lack of communication between different interest groups tend to erode trust and reduce internal development capacity. Thus, culturally heterogeneous places need particularly skilled leadership and wider involvement of interest groups in the decision making processes.

Our comparative case study showed how weak (Vormsi) or imbalanced participatory leadership (Noarootsi) raised dissatisfaction and how the ambition of the RHOs induced actions such as running for power to realise their own agendas. Local leaders of Vormsi and Noarootsi did not involve RHOs equally at the beginning. RHOs in turn did not join informal municipal networks; rather, they chose a few local collaborators to communicate with and to trust them as their representatives.

As a consequence, personal (business) interests started to dominate instead of collective values. Balanced municipal (community based) leadership was not considered important by any parties and the orchestration of various interests (the involvement of potential stakeholders in community development) was either missing or one-sided. As a result, a small number of RHOs - notably, young Estonian business persons - became strong stakeholders, increased their impact on local governance by incorporating some of the local leaders into their business schemes, and took over institutional power. However, other groups started to play a similar game, accelerating conflicts within the local councils.

Permanent residents became minorities in terms of the power relations and defending their interests in the municipal councils. The same applies to Estonian-Swedish communities: they actually own 80 percent of the land, while their influence on the municipal decision making is limited. Power games in local councils have induced some desperate actions by local people such as going to court or approaching national media to make disputed cases - which they lost at the municipal council - public. This did improve neither the image of the municipalities nor their internal solidarity. However, reflections in the national media made these places more 'visible' probably, contributing to local tourism businesses and recreational home development. Such processes call for further studies. 
We may presume, recreational house owners are definitely capable of local leadership and under certain circumstances, they aspire also for being part of it. Their intervention definitely caused a major change in local governance. It is too early to say whether it had positive or rather negative consequences in the long run, but recreational peripheries are, in many cases, less 'peripheral' due to their actions and the social capital they possess. To reduce potential conflicts and release positive synergies, it is a crucial issue to involve RHOs in community life and to improve the relationships of different stakeholders (e.g., remote villagers) as much as possible. Local leaders as well as civil servants should be more aware of social processes and the ways in which these residents can be involved in local affairs for the mutual benefit of all parties.

Future research should consider the highly complex composition of both permanent and temporary population - there are always more than two groups involved in conflicts, organised often by villages and neighbourhoods, along various motives. As changes in leadership raise emotional reactions, an additional objective for future research should be the analysis of the actual (financial, economic) results of the different types of local governance models. Moreover, the impact of the media should also be studied - as coastal areas have a very positive image per se, even negative reflections may be beneficial to those places. Finally, we must also realise that the databases available - including even the population census - do not reflect the reality of the temporary population of recreational peripheries.

\section{REFERENCES}

Ausdahl, K., Khanal, B., Raun, J. and Ruberg, G. 2014. Effects of the presence of the temporary residents on permanent residents lives. Case-study report. Nordplus intensive course, Pärnu.

BARcA, F. 2009. An agenda for a reformed cohesion policy. A place-based approach to meeting European Union challenges and expectations. Independent Report prepared at the request of Danuta Hübner,
Commissioner for Regional Policy. DG REGIO, Manuscript, $218 \mathrm{p}$.

Bø, E., Kindel, G., Orre, L. and Rohula, T. 2014 Estonian-Swedish second home owners in Noarootsi, three villages; Spithamn, Dirhamn and Rooslep. Casestudy report. Nordplus intensive course, Pärnu.

Campell, S., Albert, J.M., Durepos, G. and Wiebe, E. 2010. Encyclopedia of Case Study Research. Thousand Oaks, CA. Sage Publications.

Christaller, W. 1963. Some considerations of tourism location in Europe. Papers of the Regional Science Association 12. 95-105.

DAFT, L.R. 1998. Organization theory and design. Cincinnati, OH, South-Western Publishing Company.

Dijst, M., Lanzendorf, M. and Smit, L. 2005. Second homes in Germany and the Netherlands: Ownership and travel impact explained. Tijdschrift voor Economische en Sociale Geografie 96. (2): 139-152.

FARSTAD, M. 2011. Rural residents' opinions about recreational home owners' pursuit of own interests in the host community, Norsk Geografisk Tidsskrit/ Norwegian Journal of Geography 65. (3): 165-174.

FriedmanN, J. and Miller, J. 1965. The Urban Field. Journal of the American Institute of Planners 31. (4): 312-320.

FRISVOLL, S. 2012. Power in the production of spaces transformed by rural tourism. Journal of Rural Studies 28. (4): 447-457.

Gallent, N. 2007. Second home, community and a hierarchy of dwelling. Area 39. (1): 97-106.

Gallent, N., Mace, A. and Tewdwr-Jones, M. 2003. Dispelling a myth? Second homes in rural Wales. Area 35. (3): 271-284.

Giannias, D., Chepurko, Y., Figus, A. and Lameyikon, Y. 2010. Transformation core-periphery socio-economic relations (quality of life indices approach within European funding programmes). Journal of Organisational Transformation and Social Change 7. (3): 285-299.

Halfacree, K. 2006. 'From dropping out to leading on? British counter-cultural back-to-the-land in a changing rurality'. Progress in Human Geography 30. 309-336.

HaLl, C.M. 2015. Second homes planning, policy and governance. Journal of Policy Research in Tourism, Leisure and Events 7. (1): 1-14.

Horlings, I. 2010. How to generate sustainable European Rural Regions: The Role of Social Capital, Leadership and Policy arrangements. Regions 280. (Winter): 8-12.

Kaltenborn, B.P., Andersen, O. and Nellemann, C. 2009. Amenity development in the Norwegian mountains. Effects of recreational home owner environmental attitudes on preferences for alternative development options. Landscape and Urban Planning 91. 195-201. 
Keddie, V. 2006. Case study method. In The Sage Dictionary of Social Research Methods. Ed.: Jupp, V. London, Sage Publications.

LipkinA, O. 2013. Motives for Russian Recreational home ownership in Finland. Scandinavian Journal of Hospitality and Tourism 13. (4): 299-316.

Lundholm, E. 2006. Are Movers still the Same? Characteristics of Interregional Migrants in Sweden 1970-2001. Tijdschrift voor Economische en Sociale Geografie 98. 336-348.

Marcouiller, W.D. and Chraca, A. 2011. Recreational Homes, Amenities, and their Gateway Communities: A Summary of Extant Knowledge for Planning and Public Policy. Paper written for presentation at the World Planning Schools Congress 5-8 July, 2011, Perth, Australia.

Mintzberg, H. 1998. Covert Leadership: Note on Managing Proffesionals. Harvard Business Review 76. (6): 140-147.

Moss, L.A.G. 2006. The Amenity Migrants: Seeking and Sustaining Mountains and their Culture. Wallingford, CAB International.

Müller, K.D. 2002. Reinwenting the Countryside: German Second-home Owners in Southern Sweden. Current Issues in Tourism 5. (5): 426-446.

Nordio, I. 2014. Beyond the Transfer of Capital? Second-Home Owners as Competence Brokers for Rural Entrepreneurship and Innovation. European Planning Studies 22. (8): 16-41.

Nordin, U. and MarjavaAra, R. 2012. The local nonlocals: Recreational home owners associational engagement in Sweden. Tourism: An International Interdisciplinary Journal 60. (3): 293-305.

Norris, M. and Winston, N. 2010. Second-Home Owners: Escaping, Investing or Retiring? Tourism Geographies 12. (4): 546-567.

PARIS, C. 2009. Re-positioning Second Homes within Housing Studies: Household Investment, Gentrification, Multiple Residence, Mobility and Hyper-consumption. Housing Theory and Society 26. (4): 292-310.

Perlik, M. 2010. The problems with applying the amenity-led migration concept in a Europe context. Regions 280. (Winter): 25-27.

Pettersson, R. 1999. Foreign Second Home Purchases - The Case of Northern Sweden, 1990-96. CERUM Working Paper 14, Umeå, Umeå University.

PitKänen, K. 2008. Second-home Landscape: The Meaning(s) of Landscape for Second- Home Tourism in Finnish Lakeland. Tourism Geographies 10. (2): 196-192.

Purdy, J.M. 2012. A framework for assessing power in collaborative governance processes. Public Administration Review 72. (3): 409-417.

RaAgmaA, G., Kindel, G. and LüsI, M. 2012. Leadership and Change in Sustainable Regional Development. London and New York, Routledge, Taylor \& Francis Group.
Robertsson, L. and MarjavaAra, R. 2014. The Seasonal Buzz: Knowledge Transfer in a Temporary Setting. Tourism Planning and Development 12. (3): 251-265.

Rye, F. and BERG, G.N. 2011. The second home phenomen and Norwegian rurality. Norsk Geografisk Tiddskrift/Norwegian Journal of Geography 65. (3): 126-136.

SAYER, A. 1992. Method in Social Science: A Realist Approach. London, Routledge.

Sotarauta, M. 2009. Regional development and regional networks: The role of regional development officers in Finland. European Urban and Regional Studies 17. (4): 387-400.

Sotarauta, M. 2012. Leadership and Change in Sustainable Regional Development. London and New York, Routledge, Taylor \& Francis Group.

Stewart, S.I. 2002. "Amenity Migration". Trends 2000: Shaping the Future. Proceedings of the $5^{\text {th }}$ Outdoor Recreation and Tourism Trends Symposium, Lansing, MI, Recreation and Tourism Resources, East Lansing.

Tamm, H., Fernández, D.C., Sink, G., Alho, E. and TómasdótTiR, A.D. 2015. Consumption of space and local governance in core-periphery relations. Casestudy report. Nordplus intensive course, Tartu.

Internet sources:

Eesti Entsüklopeedia (EE), 2015. http://entsyklopeedia.ee/. 16.03.2015

Eesti Päevaleht, 2015. www.epl.ee. 16.03.2015

Lääne Elu, 2015. www.le.ee. 16.03.2015

Maaleht, 2015. www.maaleht.ee. 16.03.2015

Noarootsi valla arengukava aastateks 2013-2020 (NVA), 2012 https://noarootsi.kovtp.ee/et/vallaarengukava. 14.05.2014

Population Register, 2015. https://www.siseministeerium.ee/elanike-arv 30.06.2015

Statistics Estonia, 2015. www.stat.ee. 14.05.2015

Vormsi valla arengukava aastateks 2011-2025 (VVA), 2011. http://avalik.amphora.ee/VORMSIVV/document.aspx?id=41592. 14.05.2014 


\title{
Geography in Visegrad and Neighbour Countries
}

\section{Regional Socio-Economic Processes in Central and Eastern Europe - 20 Years in Transition and 2 Years in Global Economic Crisis}

\author{
Edited by \\ Ágnes Erôss and Dávid KarácsonyI \\ Geographical Research Institute Hungarian Academy of Sciences \\ Budapest, 2011. 169 p.
}

During the last twenty years the erstwhile Soviet bloc countries in Central and Eastern Europe (CEE) have taken distinct routes in post-socialist development, wherein the national trends and internal regional processes proved to be in deep contrast. Responses to the challenges of the global economic crisis also varied, repeatedly brought to the surface long

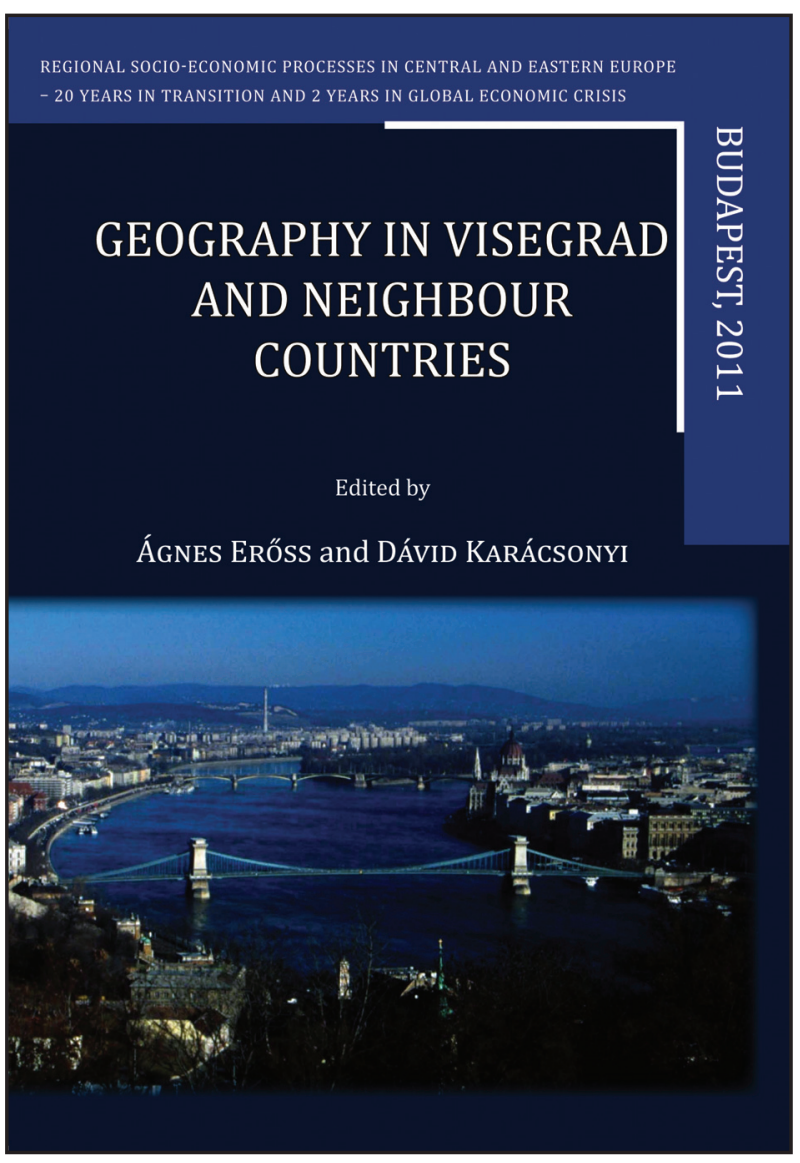
existing regional issues, structural problems and ethnic conflicts. Human geographers are divided in the assessment of the shifts that occurred during the past twenty years and the exchange of experience is vital for finding adequate answers to the new challenges. In order to provide a forum for discussion the Geographical Research Institute Hungarian Academy of Sciences with the generous support of the International Visegrad Fund Small Grant Programme organized a conference in order to induce the revival of contact between the institutes of geography of Visegrad Countries and their Western and Eastern neighbours. Present volume is a selection of presentations aiming to provide a deeper insight in socio-economic processes and their

Price: EUR 10.00

Order: Geographical Institute RCAES HAS Library, H-1112 Budapest, Budaörsi út 45.

E-mail: magyar.arpad@csfk.mta.hu 